\title{
Labour pains: Lessons from South Africa for women employees and their employers
}

\author{
Jenni Gobind and Wilfred I. Ukpere* \\ Department of Industrial Psychology and People Management, Faculty of Management, University of Johannesburg, \\ South Africa. \\ Accepted 7 November, 2012
}

\begin{abstract}
South African women make a substantive contribution to the South African workforce. Many may argue that there are more women in certain sectors than others, or more than there used to be 20 years ago. With the emergence of democracy, South African women have benefitted from progressive Labour Legislation or so it may seem. South African women have not yet reaped the rewards of such legislation. Women in the workplace are forced to relinquish their reproductive rights in return for an income. This paper unpacks maternity rights and the factors that mitigate maternity leave. These are the labour pains faced by many South African women.
\end{abstract}

Key words: Pregnancy, maternity leave, maternity rights.

\section{INTRODUCTION}

South African Labour Legislation provides substantial protections for pregnant employees. The Constitution of South Africa Act 108 of 1996 (Constitution) (Republic of South Africa,1996), the Employment Equity Act of 55 of 1998 (EEA) (Republic of South Africa, 1998), the Unemployment Insurance Act 63 of 2001 (UIA) (Republic of South Africa, 2001), the Basic Conditions of Employment Act 75 of 1997 (BCEA) (Republic of South Africa,1997), the Labour Relations Act 66 of 1995 (LRA)(Republic of South Africa,1995), and theBasic Conditions of Employment Act 75 of 1997 Code of Good Practice on the Protection of Employees During Pregnancy and After the Birth of a Child (The Code) (Republic of South Africa, 1997) protect the rights of the employee from the day she falls pregnant until after the birth of the child.

The following is a useful guideline to identifying significant legislation related to pregnancy:

Sections 9(3) and 9(4) of the Constitution of the Republic

*Corresponding author. E-mail: wiukpere@uj.ac.za,
pastorwilfred@yahoo.co.uk.

South Africa (Republic of South Africa, 1996) state that no person may be discriminated against or dismissed on account of pregnancy.

Section 6 of the Employment Equity Act (Republic of South Africa, 1998) reiterates the Constitution's prohibition against discrimination on the grounds of pregnancy.

Sections 34 and 37 of the Unemployment Insurance Act (UIA) (Republic of South Africa, 2001) provide for the payment of maternity benefits to the employee by the Unemployment Insurance Fund 63 of 2001(UIF) (Republic of South Africa, 2001) during the period of maternity leave.

An employee can claim 121 consecutive days (four months) maternity leave from the South African Department of Labour, depending on length of employment. The South African Department of Labour calculates how many credit days the employee has available based on the last 4 years of work. In short, for every 6 months that an employee has worked, the employee will receive 1 month's benefits, to a maximum of 4 months.

The UIF benefit is between $38 \%$ to $58 \%$ of an employee's salary (to a maximum of R12 478 per month), for example: 
If an employee earns R12 478 or more per month, the employee will receive R155.89 per day (about R4676 $\mathrm{p} / \mathrm{m}$ ). An employee cannot receive more than this amount from the UIF.

If the employee earns $R 5000 \mathrm{p} / \mathrm{m}$, the employee can expect about R72.96 per day (R2188 p/m).

If the employee earns $R 3000 \mathrm{p} / \mathrm{m}$ the employee can expect about R47.62 per day (R1428 p/m).

Approval of an application and payment of the first instalment of the benefit take between 6-8 weeks from the date of submission. The employee is paid for each proven day of maternity leave. After the application has been approved, the employee has to pay monthly visits to the South African Department of Labour to submit proof that she is still on maternity leave.

Since 2010, foreign workers are allowed to claim UIF from the South African Department of Labour if their employers pay UIF levies and they have a valid workpermit. These applications take longer to approve because they are sent to the South African Department of Labour's head office for approval (UIF4U, 2011:1).

Section 25 of the Basic Conditions of Employment Act (BCEA) (Republic of South Africa, 1997) requires employers to give pregnant employees four months paid maternity leave.

This leave would normally commence four weeks before the expected date of the birth, but may start earlier if a medical practitioner or midwife requires it.

The employer may not allow or require the employee to resume work before 6 weeks after the birth, unless a medical practitioner or midwife certifies that she is fit to do so.

An employee who miscarries during the third trimester or bears a stillborn child is entitled to six weeks maternity leave.

According to section 26 , no employer may require or permit a pregnant employee or an employee who is nursing her child to perform work that is hazardous to her health or the health of her child.

During an employee's pregnancy (except while on maternity leave) and for a period of six months after the birth of her child, the employer must offer her suitable alternative employment on terms and conditions that are no less favourable than her normal terms and conditions of employment.

Section 27(2) of the BCEA (Republic of South Africa, 1997) grants a total of three days paid paternity leave/family responsibility leave per annum in the event of the birth or illness of an employee's child. This only applies to an employee who has been in the employer's employ for more than four months and who works at least four days per week.

Subject to subsection (5) of the BCEA (Republic of South Africa,1997), an employer must grant an employee a day's family responsibility leave and pay the wage the employee would ordinarily have received for work on that day, which amount is payable on the employee's usual pay day.

An employee may take family responsibility leave for a whole day or part thereof. Before paying an employee for leave in terms of this section, an employer may require reasonable proof of the event, contemplated in subsection (2) of the BECA (Republic of South Africa, 1997), for which the leave was required.

An employee's unused leave entitlement in terms of this section lapses at the end of the annual leave cycle in which it accrues.

\section{Problem statement}

South African women have the benefit of protective legislation when faced with disputes relating to maternity rights in the workplace. However, with protective legislation in place, women continue to be treated unfairly often for reasons beyond their control or for reasons based on ignorance and fear. Women need to empower themselves with knowledge and confidence in their legal rights. This paper unpacks women's maternity rights and the measures used by employers to mitigate these rights.

\section{Research question}

The following research questions were considered:

1. What are maternity rights?

2. How is dismissal based on pregnancy?

3. What are the factors that mitigate maternity leave?

4. What are types of legislation that support women's rights?

\section{The aim and objectives of the paper}

The paper aims:

1. To unpack the term maternity rights within the South African workplace.

2. To discuss ways in which dismissals are unfairly based on pregnancy.

3. To investigate factors that mitigate maternity leave?

4. To explore types of legislation that support women's rights?

\section{METHODOLOGY}

The paper is a meta-analysis, which relied on secondary sources of information. It is a qualitative study that is based on conceptual analysis. It considers women's rights in terms of maternity rights from an "emic" perspective (author's viewpoint). The analysis has included a comparative review of literature relating to women's maternity rights and the relevant literature that support women's rights within the workplace. 


\section{THEORETICAL FRAMEWORK}

The code of good practice regarding the protection of employees during pregnancy and after the birth of a child (The Code), issued in terms of the BCEA (Republic of South Africa, 1997), is aimed at further protecting pregnant and post-pregnancy employees and the employee's new-born child. The Code obliges employers and employees to do the following:

Work in collaboration with employee-elected representtatives to identify and assess hazards to the health and safety of employees and, in particular, risks to pregnant or breast-feeding employees within the workplace.

Further implement appropriate measures to eliminate or control hazards, and, in particular, measures to protect pregnant or breast-feeding employees.

Supply employees with information and training regarding risks to their health, and measures for eliminating and minimising such risks, as it pertains to pregnant or breast-feeding employees.

Health representatives are required to maintain a list of jobs not involving risk, to which pregnant or breastfeeding employees could be transferred.

Pregnant employees or employees intending to fall pregnant should be encouraged to inform their employer as early as possible in order to ensure that the employer can assess risks and deal with them.

Employers should evaluate the situation of each pregnant employee individually (Israelstam, 2011. n.d:1).

\section{Dismissal on the grounds of pregnancy}

Section 187(1) (f) of the Labour Relations Act 66 of 1995 (the LRA) (Republic of South Africa, 1995) deems the dismissal of women on the ground of pregnancy to be automatically unfair. [Note: The relevant provisions establishing this right are contained in Section 9(3) and (4) of the Constitution, Section 187(I) of the Labour Relations Act 66 of 1995, and Section 6 of the Employment Equity Act of 1998 (Republic of South Africa, 1998). However, this type of protective legislation may not afford women protection against a range of other detrimental treatments short of dismissal (Grogan, 2010) such as being denied employment based on continuity of employment, concealment of pregnancy, poor performance, or reproductive and health reasons. According to Section 6 (1) of the Employment Equity Act (Republic of South Africa, 1997), these forms of treatment may be construed as unfair discrimination. The onus is on the applicant to prove that the unfair treatment relates to her pregnancy.

\section{Continuity of employment}

South African case law provides a sound guideline for dealing with matters of discrimination related to pregnancy. In the case of Woolworths (Pty) Ltd v Whitehead Ltd (South African Labour Court, 1999), Whitehead was denied employment based on the argument that the continuity of her employment would be disrupted due to her pregnancy. Presiding Judge Waglay concluded that no employer can receive any guarantee that an incumbent will remain in his or her employment for an uninterrupted period of time. The judge ruled that the matter did in fact relate to the pregnancy and that Whitehead had been discriminated against on the said grounds. No employee can guarantee a prospective employer continuity of employment as this guarantee contravenes labour legislation.

\section{Concealment of pregnancy}

In a case of Mashava $v$ Cuzen and Woods Attorneys (South African Labour Court, 2000) Mashava, an article clerk, concealed her pregnancy due to the fact that she had been newly appointed as an article clerk and was serving her probation period. Mashava was dismissed on the grounds that the trust between her and her principal had been compromised due to the concealment of her pregnancy. The judge ruled in favour of Mashava, holding that her dismissal was based on her pregnancy and not her performance as an article clerk.

Concealment of pregnancy is not a ground for dismissal; however, it is advisable that employees inform their employers of their pregnancy as early as possible as to ensure that employers can assess risks and deal with them accordingly. In the case of Mashava, the employer lost the case based on the fact that the applicant did not conceal her pregnancy to the detriment of the company. The presiding judge reiterated that the employee had the right to conceal her pregnancy for personal reasons, and that such concealment did not impact on her ability to perform her tasks. Relying on such a defence requires an understanding of the relevant legislation and the application thereof. The Code sets out the rule as a precautionary measure to guide the behaviour of employees and as a guideline to employers in handling such matters.

\section{MATERNITY AND HEALTH RIGHTS}

In a case of Wallace $v$ Du Toit (South African Labour Court, 2006), Wallace's services were terminated after the respondent discovered that she was pregnant. Wallace referred the dispute to the Labour Court, claiming that she had been unfairly discriminated against due to her pregnancy, and sought compensation under the LRA. Du Toit claimed that, during the pre-employment interview, it had been agreed with Wallace that her services would be terminated if she fell pregnant. Wallace denied having entered into such an 
agreement.

The Labour Court held that, since it could not be accepted that not being pregnant or a parent was an inherent requirement of the work, her dismissal constituted unfair discrimination. The law of contracts is clear that an unlawful clause in a contract is null and void. Simply put, one cannot enter into a contract that conflicts with an individual's human rights or the law, for example, entering into a contract agreeing to enslavement. These types of agreements infringe on the constitutional right to freedom. Agreeing to not falling pregnant conflicts with the right to reproductive health. Based on the aforementioned, the judge ruled in Wallace's favour.

The right to reproductive health is a human right that every woman is entitled to, whether she is young or old, living with HIV or not, differently-abled, heterosexual or lesbian. Reproductive health rights rest on the recognition of the basic right of all couples and individuals to decide freely and responsibly about the number, spacing, and timing of their children, and to have the information and means to do so. This includes the right to make decisions concerning reproduction that is free of discrimination, coercion and violence. Employees lack correct and accurate information regarding these rights, which diminishes their decision-making capacity (Reproductive Health, 2011).

\section{Related to pregnancy}

It may be argued that case law is quite supportive of women who have been discriminated against for factors relating to their pregnancy. The following two cases have been included to advise Human Resource practitioners to not rely on hard and fast rules, but to be conscious that, in certain instances, these rules could be exploited.

In the case of Wardlaw $v$ Supreme Mouldings (South African Labour Court, 2004), the applicant was charged with negligence and dismissed following a disciplinary hearing on her return from maternity leave. A separate disciplinary hearing was held prior to her leave, based on an incident unrelated to her pregnancy. Her maternity leave coincided with the disciplinary sanction of the first disciplinary hearing, which could not be implemented due to the pregnancy leave. Had the applicant not gone on leave, the sanction would have been implemented immediately. The applicant claimed that the reason for her dismissal was related to her pregnancy. The Labour Court held that, given the respondents detailed evidence relating to the applicant's negligence and incompetence submitted during the first disciplinary hearing, the reason for her dismissal was not related to her maternity leave.

The lesson to be learnt is, that practitioners need to be able to differentiate between incidences that relate to pregnancy and incidences that result from the normal functioning of the workplace. Violet Mokone $v$ NUM (South African Commission for Conciliation, Mediation and Arbitration, 2007), Mokone presented her case based on the fact that her daughter would be delivering her grandchild within seven or eight months. As a responsible mother, she felt that she could not desert her daughter in her state of pregnancy, and wanted to assist her until the child was at least six months old, upon which she could take her grandchild with her to Klerksdorp. She based her claim of unfair dismissal on the defence of "relates to pregnancy." The Commissioner held that Mokone had insufficient supporting evidence of such relatedness, and dismissed her claim.

This case has been included to illustrate that employees may attempt to abuse the protection granted by the rule. Therefore, the practitioner is advised to establish the grounds of "related to pregnancy."

Human resource (HR) practitioners should be aware of the flexibility of the application of the legal rule of "related to pregnancy." Applicants may be adamant in their interpretation of the rule, but it is up to an HR practitioner to address each case based on merit and relevance. South African labour legislation affords pregnant women substantial protection; however, it is the duty of practitioners not to open the flood gates of interpretation. The Code is exhaustive in its explanation of the duties of an employer with regard to a pregnant employee. If this code is adhered to, the possibility of encountering the aforementioned action would be remote.

\section{Mitigating maternity leave versus maternity protection}

Maternity protection has been a disquieting concern of the International LabourOrganization (ILO) since the first year of its existence, when the first Maternity Protection Convention, 1919 (No. 3), was adopted. The primary concerns of the ILO, with respect to maternity protection remain the same, namely to enable women to successfully combine their reproductive and productive roles, and prevent unequal treatment in employment due to their reproductive role. The ILO refers to maternity as a condition which requires differential treatment to achieve genuine equality, and in this sense, it is more of a premise of the principle of equality than a dispensation. Therefore, special maternity protection measures should be taken to enable women to fulfil their maternal role without being marginalized in the labour market (ILO, 1996:42).

Mitigating maternity leave discusses methods in which employers attempt to evade maternity paying leave by resorting to dismissal, poor performance or misconduct as an excuse to avoid paying maternity leave. This paper utilises case law as a lens in observing these unsavoury approaches. Human Resource (HR) practitioners would find the use of case law most valuable. The decisions held in the cases to follow provide a rich guideline as to human resource action that can be avoided. 


\section{THE CONSTITUTION OF THE REPUBLIC OF SOUTH AFRICA}

The Constitution (Republic of South Africa, 1996) contains an equality clause; which enshrines the right to equal protection and benefit of the law, and to the full and equal enjoyment of all rights and freedoms. It further ensures everyone the right to fair labour practices (Republic of South Africa, 1996, Section 23.1) and no person, which would seem to imply that even the father of the child, may not be unfairly discriminated against on grounds of the pregnancy of his wife or life partner. This barrier against unfair discrimination is entrenched in the Constitution of the Republic of South Africa (Republic of South Africa, 1996, Section 9: 3-4).

\section{The basic conditions of Employment Act 75 of 1997}

Pregnant employees are strongly protected under existing South African labour law. There are no fewer than six pieces of legislation that require employers to treat pregnant and post-pregnant employees with the greatest of care. One of these pieces of legislation is the Code of Good Practice on the Protection of Employees during pregnancy andafter the birth of a child (Republic of South Africa, 1997, Section 23).

The code, issued in terms of the Basic Conditions of Employment Act (BCEA) (Republic of South Africa, 1997) is aimed at protecting pregnant and post-pregnant employees. The code obliges employers to:

1. Encourage female employees to inform the employer of their pregnancy as early as possible, so as to ensure that the employer can assess risks and deal with them.

2. Evaluate the situation of each employee who has informed the employer that she is pregnant.

3. Assess risks to the health and safety of pregnant or breast-feeding employees within the workplace.

4. Implement appropriate measures to protect pregnant or breast-feeding employees.

5. Supply pregnant or breast-feeding employees with information and training regarding risks to their health and safety and measures for eliminating and minimising such risks.

6. Maintain a list of jobs not involving risk to which pregnant or breast-feeding employees could be transferred.

The Basic Conditions of Employment Act (Republic of South Africa, 1997) lays down certain minimum standards that a contract of employment must comply with. It also imposes a statutory duty on an employer to provide leave. An employer is thus compelled by law to provide for maternity leave in its contract of employment. The employee must however notify the employer in writing when the intended maternity leave will commence and when employee intends to resume work.

Section 25 of BCEA (Republic of South Africa, 1997) provides that, an employee is entitled to at least four consecutive months' maternity leave which may commence at any time from four weeks before the expected date of birth. When a midwife or medical practitioner however, certifies that it is necessary to commence with leave by reasons based on the health of the employee or that of the unborn child, this period may exceed the four months provided the employer agrees to another period.

The Act provides that no employee may be expected to work for the first six weeks after the birth of her baby. A medical practitioner or midwife may however certify that the employee is fit to work.

\section{Paid/unpaid maternity leave}

The startling fact is that the BCEA (Republic of South Africa, 1997) does not require that maternity leave should be paid and the employer is not under an obligation to provide for paid maternity leave. Some employers do however provide for paid maternity leave in that the contract of employment makes provision for an amount of days or weeks that will be paid. It is thus important to thoroughly read the contract of employment, in order to know what rights to paid maternity leave the employee willreceive during employment at a specific employer. Should the employer not make provision for paid maternity leave, the employee may claim in terms of the Unemployment Insurance Act (Republic of South Africa, 2001).

Although the BCEA (Republic of South Africa, 1997) does not provide for maternity pay, maternity benefits continue to be regulated by the Unemployment Insurance Act (UIA) (Republic of South Africa, 2001). A pregnant employee who is a contributor to theUnemployment Insurance Contributions Act (Republic of South Africa, 2002) is entitled to receive maternity benefits in terms of the UIA (Republic of South Africa, 2001). Any maternity benefit paid to the employee from another source, including a collective agreement or contract of employment, must be deducted from the statutory benefit. Maternity benefits can be paid up to a maximum period of 17 to 32 weeks. On the other hand, an employee whohas a miscarriage during the third trimester or who bears a stillborn child is entitled to the maternity benefit for a maximum of six weeks after the miscarriage or stillbirth.

Unlike the previous UIA (Republic of South Africa, 2001), which set benefits at a fixed rate of $45 \%$ of earnings, the new system favours lower-paid workers by laying down a sliding scale of benefits based on monthly remuneration.

\section{Pregnant job applicants}

Job applicants for example, have pronounced fear of 
disclosing the fact that they are pregnant during the course of a job interview, fearing that this fact could sway the employer to decide against appointing them. In the Labour Court case of Whitehead v Woolworths (South African Labour Court, 1999) the job applicant claimed that the respondent refused the applicants appointment based on her pregnancy. The presiding judge was of the view that an applicant becomes an employee only when work is actually performed in terms of the agreement or at least, when performance is tendered and refused. Since the applicant had not commenced employment the onus according to the presiding judge no longer lay with the employee. In view of the discussion the Whitehead case avoided the need to pay maternity leave by relying on legal interpretation.

Pregnant job applicants have to be weary of the content of their employment contracts. Employers are often aware of their prospective employees need for employment, this need is often exploited. Employees sign contracts of employment with the intention of securing employment whilst employers include clauses in contract of employment with the intention of binding employees to unsavoury clauses. The case of Mashava v Cuzen and Woods Attorneys (South African Labour Court, 2000) addressed the issue of non-disclosure. In this case, the respondent dismissed the applicant who was onprobation after it had discovered that she was pregnant. The applicant claimed that the respondent had accused her of lying about her pregnancy and her services were terminated. The Labour Court (LC) held that the respondent had unfairly dismissed the applicant, and therefore, ordered the payment of compensation to the applicant.

In the case of Wallace v Du Toit (South African Labour Court, 2006) the applicant was appointed as an au pair to care for her employer's two young children. After two years, the applicant fell pregnant, and her employment was terminated. The applicant claimed that he had made it clear at the pre-employment interview that the applicant would no longer qualify for employment if she had children of her own, as her loyalties to his own children would be divided, and that the employment relationship had lapsed by virtue of a "resolutive condition" having been satisfied. The applicant admitted that she and the respondent had discussed her marital status before she commenced employment, but denied that she had been told that being childless was a condition of employment. The presiding judge held the dismissal related to the applicant's pregnancy and that such a dismissal is automatically unfair in terms of section $187(1)(e)$ of the Labour Relations Act (Republic of South Africa,1995). The respondent's justification that this was an inherent requirement of the job, even if it was sustainable, which according to the judge, cannot in law provide a legal justification. The section is clear. A dismissal where the reason is related to the pregnancy of the employee is automatically unfair and cannot be justified. Employers are therefore cautioned that the inclusion of any clause in an employment contract that relates negatively to an employee's pregnancy would be seen as null and void.

\section{Maternity leave and foreign nationals}

Prior to 2010 foreign nationals with valid work permits were not allowed to claim maternity leave pay. Employers have since relied on the assumption that legislation has remained unchanged and that foreign nationals are often without valid work permits. This being the case employers continues to prejudice employees based on their poor understanding of legislation. HR practitioners need to equip themselves with changing legislation so as to ensure that their decisions are well informed.

Kanhema (2010) relates the case of Anna Chitsuwi, a Zimbabwean chain store worker. Anna was forced to take a polygraph test along with other employees as part of an internal investigation. When her employer found out that she was pregnant and could not take the test due to possible interference from her baby's heartbeat, she was accused of getting pregnant to avoid the polygraph test.

Anna soon after claimed maternity leave, she found out that her employer would not pay her, and therefore turned to the Unemployment Insurance Fund (UIF) (Republic of South Africa, 2001) which in turn stipulated that she will be paid as she is a foreign national working legally in South Africa.

"Faced by the fact that I was not going to be paid whilst on my four months of maternity leave I was forced to stay at work until the baby was almost full term, which was risky," she said, adding "I was also forced to go back to work early since I needed the money. That means I had less time with my child" (Kanhema, 2010).

Chitsuwi is a Zimbabwean immigrant, but said her South African friends do not have it any better when it comes to maternity protection in the workplace, especially single mothers, some of whom have ended up in despair and resorted to abortion after failing to secure maternity benefits from their employers or the fathers of their babies.

A combination of low wages, failure by employers to comply with labour regulations stipulating the benefits employees are entitled to and complications in the process of obtaining maternity benefits from government funded programmes, has led to many women either losing their jobs after giving birth or risking their health to retain their jobs. As of 2010, foreign nationals can claim Unemployment Insurance (UIF) provided they have a valid work permit and make a contribution to the Unemployment Insurance Fund (UIF4U, 2010).

\section{The Labour Relations Act No 66 of 1995}

Section 187(1) (e) of the Labour Relations Act (Republic 
of South Africa, 1995) prohibits the dismissal of an employee for any reason related to her pregnancy. In fact, this section makes such a dismissal automatically unfair.

This effectively means that such a dismissal:

1. Breaches a basic right of the employee,

2. Can never be justifiable and

3. Merits compensation to be paid by the employer up to an amount equivalent of 24 months' remuneration.

In practice this means that a pregnant employee or and employee with a new born baby has an inherent right to her job provided that:

1. She behaves and works according to the employer's standards.

2. She has not been so incapacitated due to illness or injury that she is unable to do her duties.

Retrenchment is not justified. Therefore, should the employer fire the employee due to pregnancy or should the employer wish to use the pregnancy as an excuse for getting rid of the employee the courts will be most likely to come down very hard on the employer.

Two recent cases demonstrate this point.In the case of Mnguni vs. Gumbi (South African Labour Court, 2004), Mnguni a receptionist in medical practice claimed that she was dismissed because she complained that she felt tired while she was in the advanced stages of pregnancy. The respondent claimed that the applicant had not been dismissed but only sent home. However, the presiding judge concluded that therespondent had employed a new receptionist the very next day. The respondent had not called on the applicant to return to work when the opportunity arose. This suggested that the applicant had in fact been fired. The dismissal was automatically unfair. The respondent had to pay the applicant 24 months'remuneration in compensation. In the case of Lukie vs. Rural Alliance cc (South African Labour Court, 2004); Lukie the applicant was dismissed when she told the manager that due to her pregnancy she needed maternity leave. Initially her manager had agreed to the maternity leave but later changed his mind and told her that she need not return to work after her maternity leave.

As with the Mnguni case (South African Labour Court, 2004), the aforementioned employer denied that the employee had been dismissed saying that the employee had left the employment on her own accord. Neither the employee nor the manager had any corroborating evidence and the court had to consider which of their testimonies was most probable.

The manager had testified to a meeting where he discussed the employer's operational requirements with the employee. However, the employee denied that such a meeting had taken place because the manager's testimony regarding the alleged meeting was vague and contradictory; the judge accepted the employee's version.
Furthermore, the employer had not denied dismissing the employee when challenged with this by an official from the Department of Labour. The presiding judge therefore found that there was a dismissal, that it was automatically unfair and ordered the employer to pay the employee 18 months' remuneration.

These cases suggest that even where evidence of dismissal is not clear, if there is any evidence of an employee being dismissed due to pregnancy, employers cannot expect leniency from the courts.

\section{Intended pregnancy: Difficulties when identifying the true reason for dismissal}

Section 187(1)(e) of the LRA (Republic of South Africa,1995) as stated above provides that a dismissal is automatically unfair if the reason for dismissal is related to the employee's pregnancy, intended pregnancy, or any reason related to pregnancy. However, as Grogan (2003:137) indicates that the phrase of "intended pregnancy" could create some difficulties when identifying the true reason for dismissal. Respondents are quick to rely on intended pregnancy as a defence. One could argue that just as employers refuse to pay maternity leave so too are employees readily motivated to rely on a defence that would allow for speedy reimbursements without the necessary evidence. The HR practitioner needs to evaluate each case based on its own merit. What may appear as grounds based on intended pregnancy at the surface, may not be the case under scrutiny. The question which arises is whether or not the employee had been automatically unfairly dismissed as a consequence of her pregnancy or any reason related to her pregnancy. Once it is common cause that the employee's pregnancy has operated against her, the employer would become burdened with an evidentiary onus which would oblige the employer to present evidence to persuade the court of the merit of its case.

Previous cases describe the employee as individuals being discriminated for reasons related to pregnancy or intended pregnancy. The following cases discuss defences raised by respondents claiming automatically unfair dismissal based on intended pregnancy. The purpose for the juxtaposition is to alert the HR practitioner to the thin line that may exist when deciding if, the defence, when raised is correct.

The case of Uys v Imperial Car Rental (Pty) Ltd (South African labour Court, 2007) illustrates the effect of section 187 (1) (e). Three days upon being appointed to a post in the office of the respondent's national credit manager, the applicant informed her superior that she was pregnant. The superior became angry, but told her to sign her letter of appointment because she was already employed by the respondent. About two weeks later, the applicant was called to a disciplinary inquiry and charged with gross 
negligence for losing a number of debtors' files, with inflating salary she claimed to have earned from her previous employer, and with unsatisfactory work performance. She was found guilty of the charges and was subsequently dismissed. She claimed that she had been dismissed because she was pregnant, and that her dismissal was automatically unfair.

The judge rejected the view that the loss of the files was contrived by the respondent to provide a justification for dismissing the applicant because of her pregnancy. It was noted that the more probable cause of the breakdown was the manager's discovery that the applicant had inflated her salary. The judge accordingly held that the applicant's dismissal was not automatically unfair.

The case of Wardlaw v Supreme Mouldings (Pty) Ltd (South African labour Court, 2004), the applicant was charged with negligence and was dismissed following a disciplinary hearing on her return from maternity leave. She claimed that the reason for her dismissal was related to her pregnancy. The judge held that given the respondent's detailed evidence of the applicant's negligence and incompetence, the true reason for her dismissal was not related to her taking maternity leave. The applicant therefore was ordered to pay the respondent costs.

The case of Rawlins v Dr. DC Kemp t/a Centralmed (South African Supreme Court of Appeal, 2011) arises from the dismissal of Dr. Rawlins, a pregnant employee (the appellant) from the employment of Dr. Kemp (the respondent). Soon after the dismissal occurred Dr. Kemp accepted that it was unfair. Dr. Kemp offered to reinstate Dr. Rawlins on numerous occasions but on each occasion the offer was refused. Dr. Rawlins said in evidence that she refused the offers because the relationship of trust had broken down. The dispute in the litigation that followed was confined to whether she should be awarded compensation.

Alleging that she had been dismissed on account of her pregnancy, Dr. Rawlins referred the matter to the Commission for Conciliation, Mediation and Arbitration through the offices of her union, claiming compensation from Dr. Kemp. Dr. Rawlins commenced proceedings in the Labour Court on 22 September, 1998 in which she claimed a declaration that her dismissal had been 'automatically unfair' or alternatively, a declaration that her dismissal had been otherwise unfair. She claimed in each case, the maximum amount of compensation that the statute allows.

At the Labour Court, presiding Judge Gush found that Dr. Rawlins had not been dismissed on account of her pregnancy, but that her dismissal was nonetheless unfair. Dr. Rawlins subsequently appealed the decision of which the appeal was dismissed. Dr. Rawlins attempted to mask her application as dismissal based on pregnancy when in fact her reason for referring the matter to the Labour Court was one of trust and possibly retribution.

\section{Mitigating maternity leave}

Under this circumstance, the HR practitioner is under immense pressure on how she/he should test for fairness. An enquiry as to fairness, would involve a moral or value judgment taking into account all the circumstances. Following the constitutional paradigm, the first step is to examine the extent to which the alleged discrimination impacts negatively on the rights or interests of the applicant.Once discrimination has been established, the question becomes how a court will determine the unfairness. If the HR practitioner is able to foresee that the employee is able to show that the employer's reason for dismissal is one which is automatically unfair under the statute.

In the Whitehead (South African Labour Court, 1999) case, the Labour Court dealing directly with the issue of fairness held that there was room for a more general defence. In determining unfairness it relied on the following elements:

1. The impact of the discrimination on the complainant;

2. The position of the complainant in society;

3. The nature and the extent of the discrimination;

4. Whether the discrimination has a legitimate purpose and to what extent it achieves that purpose;

5. Whether there are less disadvantageous means to achieve the purpose;

6 . Whether and to what extent the respondent has taken reasonable steps to address the disadvantage caused by the discrimination, or to accommodate diversity.

According to the explanation given by the Labour Court in the Whitehead case all of the aforementioned factors when assessed objectively, will assist in arriving at a level of accuracy similar to the Constitutional test of unfairness (South African Labour Court, 1997). They however, do not constitute a closed list. The HR practitioner is encouraged to rely on further reading, case law, her experience and ethics when determining fairness.

\section{PRACTICAL IMPLICATION FOR HR PRACTITIONERS}

The HR practitioner is advised to abide by rules set out in legislation, when in doubt or at a loss in finding the correct piece of legislation, relying on the Constitution as a compass. Do not assume that the law remains unchanged read up on amendments, and keep abreast on national and international labour discussions. Develop a habit of systematically evaluating case law, by focusing on facts similar to the case at hand. Often threads of insight would tend to nudge the HR practitioner towards a knowledgeable decision.Contemplate advice from a reputable labour law expert when in doubt, choosing to do so, may avoid costly litigations. 


\section{CONCLUSION}

Recounting the words of Anna Chitsuwi, South Africans do not have it any better when it comes to maternity protection in the workplace. Especially single mothers, some of whom have ended up in despair and resorted to abortion after failing to secure maternity benefits from their employers or the fathers of their babies. This suggests that legislators assume that maternity benefits are being delivered to the female workforce, yet extrinsic factors allow for the mitigation of maternity leave at the cost of the beneficiary. Case law advises us that the fault may not lie with the employer but also with the employee who relies on the defence of pregnancy or intended pregnancy when the need arises. The responsibility lies with practitioners to set the proverbial record straight, and ensure that the administration of legislation is always upheld.

\section{REFERENCES}

Grogan J (2010). Employment Rights, Juta Law: Lansdowne. Cape Town. South Africa.

Grogan J (2003). Workplace Law, 7th Ed. Juta Law: Lansdowne. Cape Town. South Africa.

International Labour Organisation (ILO) (1996), Equality in employment and occupation, Report III (Part 4B), p.42 International Labour Conference, 83rd Session, Geneva, 1996 (Geneva).

Kanhema T (2010) Maternity Leave: African Women Fight Not Alone Anymore [online] available www.wageindicator.org (Accessed 12 April 2012).

Israelstam L (2011). Employers: Beware Breaching Pregnancy Rights [online] available http://www.labourlawadvice.co.za/ (Accessed 22 July 2011).

Reproductive Health Womensnet (2011). (n.d) [online] available www.womensnet.org.za/theme/reproductive-health-amp-rights (Accessed 22 July 2011).

Republic of South Africa Constitution (1996). Act No 108 of 1996. Government Printers: Pretoria.

Republic of South Africa (1997). The Basic Conditions of Employment Act 75 of 1997 Government Printers: Pretoria.

Republic of South Africa (1997). The Basic Conditions of Employment Act 75 of 1997: Code of Good Practice on the Protection of Employees during Pregnancy and After the Birth of a Child.Government Printers: Pretoria [online] availablehttp://www.workinfo.com/free/Sub_for_legres/Data/cgppreg1 .htm (Accessed 12 July 2012).

Republic of South Africa (1997). The Basic Conditions of Employment Act No 75 of 1997 Section 23. Government Printers: Pretoria

Republic of South Africa (1996). The Constitution of South Africa Act 108 of 1996: Government Printers: Pretoria.

Republic of South Africa (1998). The Employment Equity Act of 55 of 1998 Government Printers: Pretoria.

Republic of South Africa (1995). The Labour Relations Act 66 of 1995, Government Printers: Pretoria.

Republic of South Africa (2001). The Unemployment Insurance Act 63 of 2001 Government Printers: Pretoria.

Republic of South Africa (2002). Unemployment Insurance Contributions Act No 4 of 2002. Government Printers: Pretoria.
South African Commission for Conciliation Mediation and Arbitration (CCMA) (2007) ARBITRATIONAWARD Case Number: NW6778 - 06 Commissioner: Lazarus MagaleMatlala Date of Award:21-May-2007 In the ARBITRATION between Violet Mokone v NUM NW6778-06 [online] available http://www.legalinfo.co.za/content/display.cfm?uid= C\%3A\%5CLegalData\%5CCCMA1998\%5CNW6778\%2D06\%2Ehtm (Accessed 22 July 2011).

South African Labour Court (1997). Harksen v Lane NO and Others (CCT9/97) [1997] ZACC 12; 1997 (11) BCLR 1489; 1998 (1) SA 300 (7 October 1997) Durban: Butterworths Law Reports [online] available http://www.saflii.org/za/cases/ZACC/1997/12.htm (Accessed 16 April 2012).

South African Labour Court (1999). Whitehead v Woolworths (1999) 20 ILJ 2133 (LC); [1999] 8 BLLR 862 (LC). 1. CCMAil December 2007[online] available http://www.ccma.org.za/Display.asp?L1=45\&L2=153 (Accessed 12 April 2012).

South African Labour Court (1999). Woolworths (Pty) Ltd v Whitehead Ltd 8 BLLR 862 Durban: Butterworths Law Reports.

South African Labour Court (2000). Mashava v Cuzen\& Woods Attorneys 6 BLLR 691 (LC)Durban: Butterworths Law Reports.

South African Labour Court (2000). Mashava v Cuzen\& Woods Attorneys (2000) 9 LC 8.29.1 CCMAil December 2007Durban: Butterworths Law Reports [online] available http://www.ccma.org.za/Display.asp?L1=45\&L2=153 (Accessed 12 April 2012)

South African Labour Court (2004). Lukie v Rural Alliance cc (2004) 8 BLLR 769Durban: Butterworths Law Reports [online] available http://www.labourlawadvice.co.za/ (Accessed 15 April 2012).

South African Labour Court (2004). Mnguni v Gumbi (2004) 6 BLLR 558Durban: Butterworths Law Reports [online] available http://www.labourlawadvice.co.za/. (Accessed 15 April 2012).

South African Labour Court (2004). Wardlaw v Supreme Mouldings (Pty) Ltd 13 8.29.1Durban: Butterworths Law Reports

South African Labour Court (2004). Wardlaw v Supreme Mouldings (Pty) Ltd (2004) 13 LC 8.29.1 CCMAil December 2007Durban: Butterworths Law Reports [online] available http://www.ccma.org.za/Display.asp?L1=45\&L2=153 (Accessed 12 April 2012).

South African Labour Court (2006) Wallace v Du Toit (2006) 8 BLLR 757 (LC) CCMAil December 2007Durban: Butterworths Law Reports [online] available http://www.ccma.org.za/Display.asp?L1=45\&L2=153 (Accessed 12 April 2012).

South African Labour Court (2006). Wallace v Du Toit 8 BLLR 757 (LC)Durban: Butterworths Law Reports

South African Labour Court (2007). Uys v Imperial Car Rental (Pty) Ltd (2007) 3 BLLR 270 (LC) CCMAil December 2007Durban: Butterworths Law Reports [online] available http://www.ccma.org.za/Display.asp?L1=45\&L2=153 (Accessed 12 April 2012).

South African Labour Court (2011). Rawlins v Dr DC Kemp t/a Centralmed (483/09) [2010] ZASCA 102; [2011] 1 All SA 281 (SCA); (2010) 31 ILJ 2325 (SCA); [2011] 1 BLLR 9 (SCA) (7 September 2010)Durban: Butterworths Law Reports [online] available http://www.saflii.org/za/cases/ZASCA/2010/102.html (Accessed 16 April 2012).

UIF for Moms, (2011) [online] available http://www.uif4moms.co.za/maternity.html(Accessed 28 July 2011) UIF4U (2010) Maternity Benefit Applications. [online] available http://www.uif4u.co.za/index.php?option=com_content\&view=article\&i $\mathrm{d}=39 \&$ Itemid=41 (Accessed 15 April 2012). 